\title{
The role of stress in heart failure - ground for sex specific pathophysiology
}

\author{
M. Heffer ${ }^{1}$, L. Zibar ${ }^{2}$, B. Viljetic ${ }^{3}$ Z. Makarovic ${ }^{4}$ \\ ${ }^{1}$ Department of Medical Biology, School of Medicine, Josip Juraj Strossmayer University of Osijek \\ 4, Huttlerova St., Osijek, Croatia, 31000 \\ ${ }^{2}$ Department of Pathophysiology, School of Medicine, Josip Juraj Strossmayer University of Osijek \\ 4, Huttlerova St., Osijek, Croatia, 31000 \\ ${ }^{3}$ Department of Chemistry, Biochemistry and Clinical Chemistry, School of Medicine, Josip Juraj Strossmayer University of Osijek 4, \\ Huttlerova St., Osijek, Croatia, 31000 \\ ${ }^{4}$ Department of Cardiology, Clinical Hospital Osijek \\ 4, Huttlerova St., Osijek, Croatia, 31000 \\ mheffer@mefos.hr
}

\begin{abstract}
In the last hundred years modern society went through numerous changes in life style, dietary habits, work load, physical activity and other environmental factors. As a species we are not well adapted to new demands. Higher levels of stress hormones provoke various effects, especially gradual change in the sensitivity of adrenergic, glucocorticoid and insulin receptors. All these changes are mutually associated and they gradually lead to metabolic syndrome, obesity, diabetes, heart failure and other types of pathology depending on genetic makeup and environmental factors. The aim of this paper is to summarize current knowledge concerning the impact of stress on cardiac function. Whereas stress response is sex specific we would emphasize a potential difference in pathophysiology of ischemic heart failure in men and women. Modern medicine has misinterpreted autonomous nervous system functions for years and this was reflected in heart failure (HF) and arterial hypertension therapy. Stress before the onset of menopause has a lesser effect on cardiac function compared to stress after menopause. Postmenopausal women have a significantly higher risk of heart disease, which is related to the diminished protection of the female hormonal cycle, but low doses of estrogen have not proven protective in postmenopausal women. Potential new targets of sexspecific cardiac therapy would come from better understanding of the molecular mechanisms exerted by nuclear receptors for steroid hormones, transcription factors involved in heart remodeling, cross-talk in adrenergic signaling pathways and their down-stream molecules.
\end{abstract}

Keywords: heart failure, stress, adrenergic receptors, sex specific.

Introduction. America's top 15 most prescribed drugs by dispensed prescriptions published on the internet pages (www.forbes.com/2010/05/11/; source - IMS National Prescription Audit) belong to the top six categories: pain killers, blood pressure and cholesterol lowering drugs, medication of hypothyroidism, anxiety/depression and type two diabetes. Six out of top 15 are blood pressure lowering medications. A huge mar-

\footnotetext{
(C) Institute of Molecular Biology and Genetics NAS of Ukraine, 2011
}

ket of 83 million dollars in the year 2010 belongs to the second most prescribed medication - simvastatin - a drug efficient in cholesterol lowering. If Dr. Hans Selye, the scientist who established stress reaction, would be asked to interprete such data, he would recognize population based symptoms of the most common modern disease - chronic stress. Number of scientific publications on this subject doubles every few years, but it seems like we still do not have a handle on the large scale health risks caused by the new pande- 


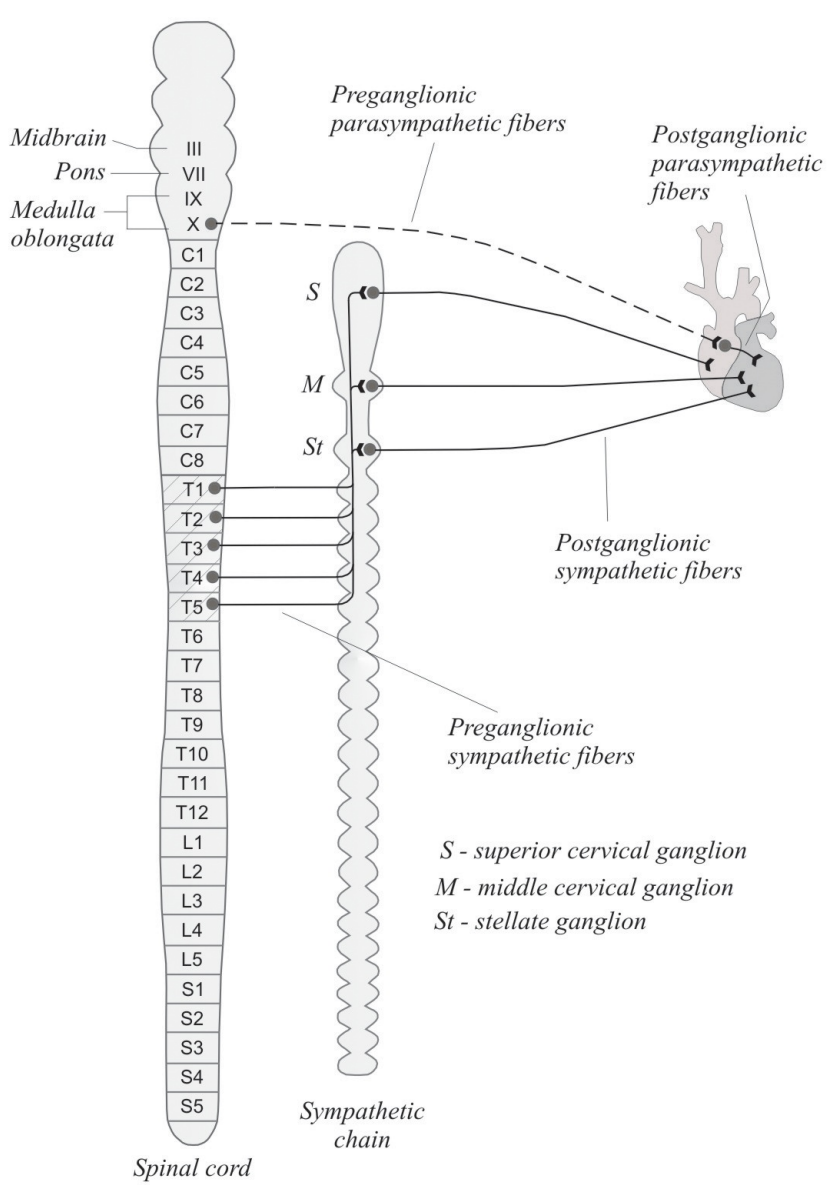

Fig. 1. The anatomy of sympathetic and parasympathetic efferent connections of the heart

mic. Trained as medical doctors, we often look after patients as removed from their social environment and make conclusions based on the currently presented isolated set of symptoms. In this paper we try to bring together pieces of knowledge connecting autonomous nervous regulation of the heart's function, major signaling pathways executing molecular instructions in stress response and the role of stress in the development of heart failure. Special notice should be taken of sexspecific molecular mechanisms, suggesting a difference in pathophysiology.

The anatomy of cardiac innervations. Two branches of the autonomous nervous system, parasympathetic and sympathetic, fight for the same targets, opposing and/or modulating each other. Each branch consists of efferent and afferent fibers. The efferent parasympathetic innervations of heart (Fig. 1) originate in medullar nuclei (nucleus ambiguous, nucleus tractus solitarius and dorsal motor nucleus), whose axons fol- low vagal nerve to intrinsic ganglia located on epicardial surface of atria [1]. Postganglionic fibers of intrinsic ganglia cross AV groove, penetrate myocardium and terminate in subendocardium (more atrial then ventricular) modulating SA and AV nodal function [2]. Acetylcholine, exclusive neurotransmitter of the efferent parasympathetic branch, operates through nicotinic receptor on preganglionic neurons and muscarinic receptors expressed on cardiomyocytes [3]. The density of muscarinic receptors is much higher in the atria compared to the ventricles [4], this is reflected in a lesser effect on the contractility than on the heart rate. Along predominant subtype $\mathrm{M}_{2}$, receptors $\mathrm{M}_{3}$ and $\mathrm{M}_{4}$ are up-regulated in the heart failure (HF) [5]. Muscarinic receptors on cardiomyocytes and conductive system are Gi protein-coupled, causing decrease in cellular cAMP and decreasing contractile forces and velocity [3].

More prolific efferent cardiac sympathetic innervations originate from the intermediolateral cell column of the spinal cord (commonly from T1 till T5), follow spinal nerves until superior, middle and stellate cervical ganglion as well as upper thoracic ganglia [2]. The postganglionic fibers arising from sympathetic trunk follow the coronary arteries and penetrate myocardium. Neurotransmitter of the sympathetic branch is norepinephrine, but cotransmission of epinephrine is well documented in panic disorder [6] and essential hypertension [7], in which case catecholamine level released by sympathetic nerves is increased for $10 \%$. Another neurotransmitter, neuropeptide Y (NPY) is readily found in sympathetic nerve of gut and liver [8] of healthy individuals, but also is acutely released during maximal aerobic exercise at high rates of cardiac nerve firing and chronically released in patients with HF [9]. Catecholamine work through two major classes of adrenergic receptors (AR), $\alpha\left(\alpha_{1} \alpha_{2}\right)$ and $\beta\left(\beta_{1}, \beta_{2}, \beta_{3}\right)$, members of the super family of $G$ protein-coupled receptors (Fig. 2). Different subtypes of $\alpha$-ARs regulate cardiac contractility and peripheral resistance; $\alpha_{1 A^{-}}$ and $\alpha_{1 \mathrm{~B}}$-constitute the majority of cardiac $\alpha$-ARs [10], $\alpha_{1 D}$ - is predominant AR of human coronary arteries [11], while three subtypes of $\alpha_{2}-A R\left(\alpha_{2 A}, \alpha_{2 B}\right.$ and $\left.\alpha_{2 C}\right)$ mediate vasodilatation of arteries, vasoconstriction of veins, platelet aggregation and various endocrine responses to the sympathetic stimulation [12]. Taking a 


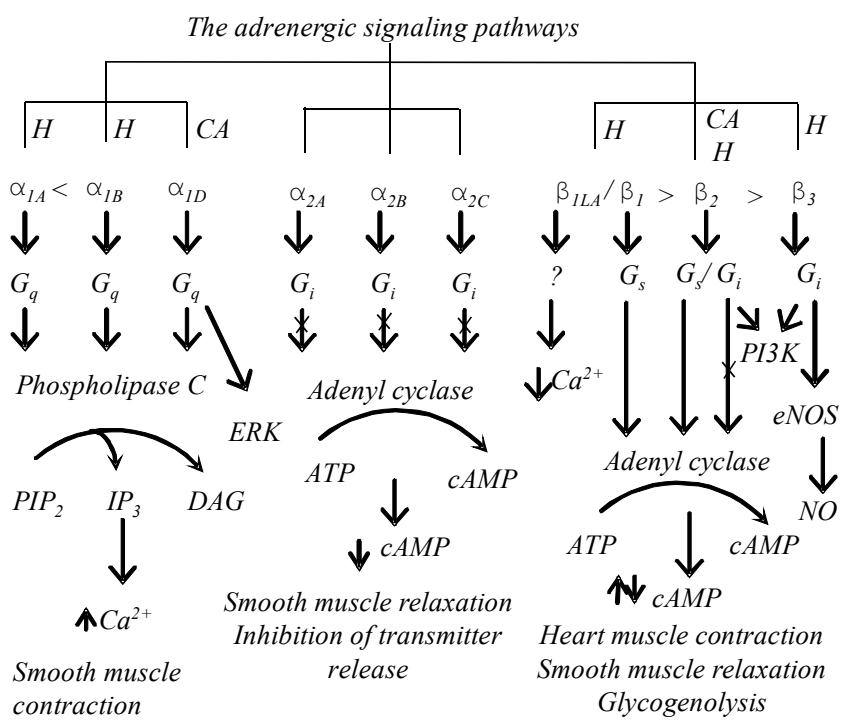

Fig. 2. Family of adrenergic receptors and their down-stream signalling pathways; $\mathrm{H}$ - heart; $\mathrm{CA}$ - coronary artery

closer look at cardiac distribution of $\alpha_{1}$-ARs reveals much higher amount of $\alpha_{1 \mathrm{~B}}$ - then of $\alpha_{1 \mathrm{~A}}$-AR and much higher amount of $\alpha_{1}$-ARs in the ventricles than in the atria [4].

The cardiac response to catecholamine stimulation in healthy mammalian heart is predominantly mediated by $\beta$-AR as follows; $70-80 \%$ by $\beta_{1}, 20-30 \%$ by $\beta_{2}$ and $\beta_{3}$ account just minimal contribution $[4,13]$. Using the functional criteria, sensitivity toward typical $\beta_{3}$-AR agonist CGP-12177 in $\beta_{3}$-knockout mice $[14,15]$, as well as molecular cloning techniques [16] it has been established that $\beta_{1}$-AR exist in multiple active conformations functionally opposing each other. All adrenergic receptors respond to both, norepinephrine and epinephrine, but they are not equally sensitive to these stimuli and the final outcome of the ligand binding depends on the intracellular signaling pathway. Increased force of contraction, accelerated relaxation and increased beating rate are outcome of the activation of Gs protein by $\beta_{1}$ - and $\beta_{2}$-AR, followed by activation of adenylate cyclase, production of cAMP and activation of protein kinase A (PKA) [17]. PKA mediates short-term inotropic effect by phosphorylation of few $\mathrm{Ca}^{2+}$ channels or pumps (sarcolemmal L-type $\mathrm{Ca}^{2+}$ channels, phospholamban - sarcoplasmatic $\mathrm{Ca}^{2+}$ pump and sarcoplasmatic SR $\mathrm{Ca}^{2+}$ release channels) and proteins reducing myofilament $\mathrm{Ca}^{2+}$ affinity (troponin I and myosin binding protein $\mathrm{C}$ ). Prolonged activation of this signa- ling pathway either leads to long-term enhancement of contractility ( 24 hours) or myocyte apoptosis and necrosis, due to intracellular $\mathrm{Ca}^{2+}$ increase and activation of $\mathrm{Ca}^{2+}$ calmodulin-dependent protein kinase II (CaMKII) $[18,19]$. A low-affinity site (or isoform) of $\beta_{1}$-AR is 40 -fold more efficient in arrhythmic potency through $\mathrm{Ca}^{2+}$ induced $\mathrm{Ca}^{2+}$ release than the regular $\beta_{1}$-AR [20]. Receptors $\beta_{2}$ and $\beta_{3}$ provide protection from adverse outcome through coupling $\mathrm{Gi}$ and activating phosphatidylinositol 3-kinase (PI3K)-protein kinase B, which determines cell survival [21] or nitric oxide (NO) production, which inhibits myocyte contraction $[22,23]$. Differently than in dogs and rodents, $\beta_{3}$ response is negligible in primates [24]. The low-affinity form of $\beta 1$-AR has chronotropic and arrhythmic effects $[20,25,26]$. The variety of catecholamine receptors provides functional differences either on the level of receptor itself (distribution, affinity for ligand and $\mathrm{G}$ protein, mechanism of density regulation) or on the down-stream levels (signaling mechanism). When cardiomyocytes or intrinsic ganglion cells express more than one receptor (what they usually do) final response depends on signaling cross-talk, a very interesting field for pharmacological investigation and intervention. Most of these studies were done on animal models (rat, dog or rabbit) and the results need further justification in human medicine.

Both branches of autonomous nervous system also posses afferent fibers (Fig. 3) providing feedback impulses for local reflexes and informing higher integrative centers (nucleus of the solitary tract, nucleus dorsalis $n$. vagi, medial and ventral forebrain). The sparse number of cardiac visceral sensory neurons sits in the dorsal root ganglia (C6-T8) or in nodose ganglion [27, 28]. Although their function is maintaining balance between sympathetic and parasympathetic stimulation during aging is crucial, they have just recently been investigated [29]. Aging is accompanied with a severe reduction of sympathetic afferent neurons; the number of neurons in old rats was just $15 \%$ of the number in juvenile animals. Physiological and pathophysiological conditions leading to the preservation or smaller reduction in the number of autonomous neurons have not been investigated yet.

The interconnection of parasympathetic and sympathetic fibers becomes even more complicated after 


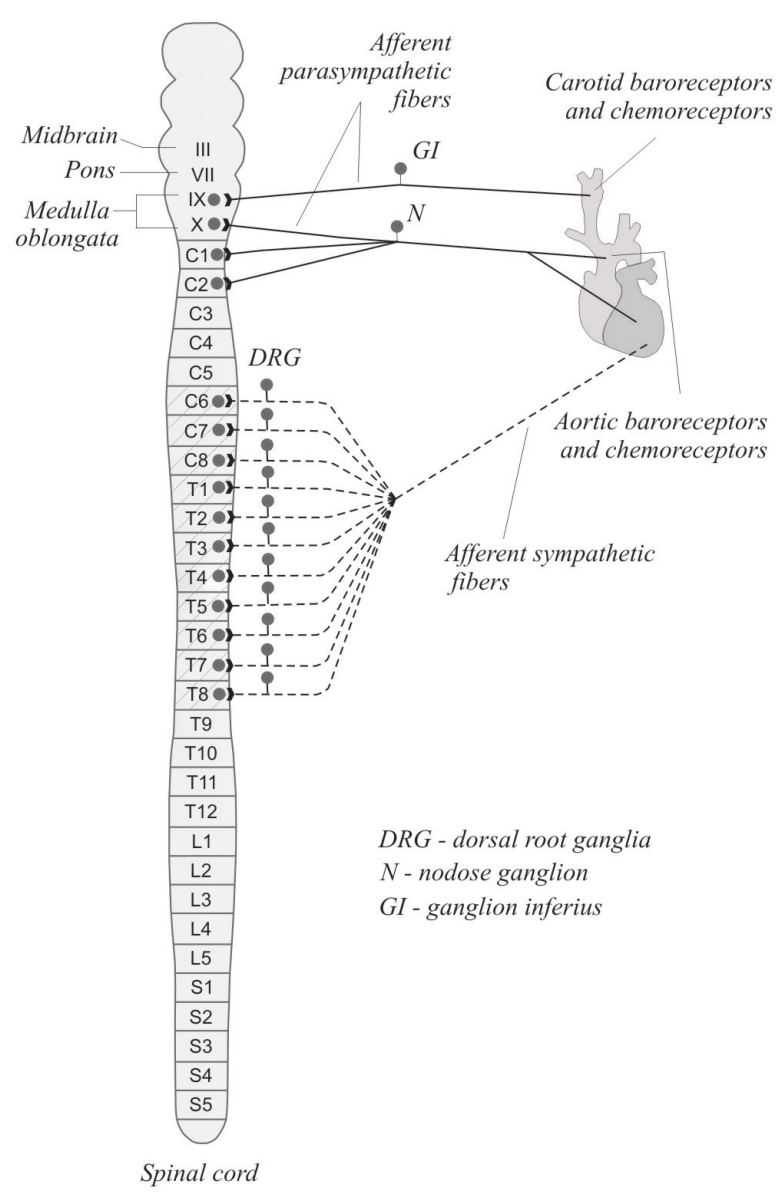

Fig. 3. The anatomy of sympathetic and parasympathetic afferent connections of the heart

finding sympathetic efferent neurons in intramural places [1]. Armour suggested three levels of cardiac autonomous regulation; the simplest one, intrinsic and working on short range-bit to bit; the second one on the level of cardiac plexus and nodose ganglion, working on middle range-minutes or hours; the tertiary level located in the medulla oblongata and cortical centers providing long lasting changes (days, months or even years).

Cardiac innervations are still not fully understood and further studies need to deal with effects of overstimulation, sex-specific aging and potential of regeneration.

Sympathetic excitation in the development of cardiovascular pathology. HF is associated with decreased inotropic response. At first glance, pharmacological treatment at the level of $\alpha_{1}$ and $\beta_{1}$-AR should lead to an improvement. Non-selective agonists, including epinephrine and norepinephrine, have adverse ef- fects like hypertension and arrhythmia [30] due to $\alpha$ AR stimulation. The development of more selective agonist for $\beta_{1}$-AR was the next logical step. Dopamine infusion at intermediate doses stimulates predominantly cardiac $\beta_{1}$-AR, while lower doses work just on dopamine receptors in splanhnic and renal arterial bed [31]. Dopamine was neglected as a possible compound for long term treatment because of the respiratory depressant effect [32] and overall unpredictable outcomes in HF [33]. Neither one of the next generation, more selective $\beta_{1}$-AR agonist (prenalterol, xamoterol, dobutamine), was more successful [34-36]. Creation of a highly selective agonist was the ultimate goal till the end of the nineties. Some tried to overcome receptor specificity barriers by designing inhibitors of down-stream signaling molecules. Milrinone and enoximone are selective inhibitors of cAMP-specific phosphodiesterase (PDE) III isoenzyme in myocardium and smooth muscle, prolonging the half life of cAMP and increasing intracellular $\mathrm{Ca}^{2+}$, both without benefit over placebo $[37,38]$ in long term treatment of ischemic heart failure. Milrinone was found to be beneficial in treatment of dilated cardiomyopathies, treatment of low output syndrome following cardiac surgery and patients with congestive HF prior to cardiac surgery due to a combination of anti-apoptotic and positive inotropic effects [39].

The large, randomized, double blind placebocontrolled clinical trials were over and over pointing to either the goal of finding selective agonist was tricky to achieve or the concept of sympathomimethic boost to failing heart was wrong. The paradigm of the failing heart craving more sympathetic stimulation was fed by findings of both anatomical and functional cardiac sympathetic denervation. Chidsey and Braunwald performed studies on excised atrial tissue obtained during heart surgery [40] and found a significant reduction of norepinephrine concentration in the failing heart. Allman and coworkers interpreted positron emission tomography with carbon-11-hydroxyephedrine (radioisotope taken up by sympathetic nerves) after acute myocardial infarction as patchy denervation [41]. Also, progression of $\mathrm{HF}$ is accompanied with $\beta$-AR selective down regulation $[42,43]$. Approximate ratio of 50:50 $\beta_{1} / \beta_{2}$-AR is not just shifted in favor of $\beta_{2}$-AR, yet both receptors become uncoupled of their down-steam signaling pathways and desensitized to adrenergic stimu- 
lation [44-46]. All of this data justified the use of $\beta-A R$ agonist, but clinical results were showing the opposite.

One of the crucial pieces in the puzzle came from Cohn and coworkers' study [47] in which they measured plasma norepinephrine at supine rest and found high correlation between concentration of norepinephrine in venous blood and risk of mortality. The concentrations of resting norepinephrine in their study remain stable on successive days, and were a sign of general sympathetic-nervous-system activation, while epinephrine was a marker of acute stress response [48] and variable from day to day. Similar data were coming out of succeeding studies $[49,50]$ proving that in untreated patients with congestive heart disease cardiac norepinephrine spillover was increased as much as 50-fold, that corresponded to the levels in healthy adult during near maximal exertion. Increased cardiac adrenergic drive preceded generalized sympathetic activation [51] and manifested as 4-5 times higher than normal norepinephrine spillover in the mild HF, as well as in a heart with a predisposition for ventricular tachycardia and ventricular fibrillation [52]. Along with norepinephrine the spillover of NPY [8], neuropeptide which is not subjected to neuronal reuptake and have been shown to cause coronary vasoconstriction, inhibiting vagal activity and triggering ventricular arrhythmias through $Y(2)$ receptors [53], also increases. Beside peripheral drive, in the rat coronary ligation model, norepinephrine is also increased in the central nervous system in the locus coeruleus and nucleus in which its project - paraventricular nucleus of the hypothalamus - the one which participates in the regulation of autonomous nervous system [54, 55].

In the meantime, transgenic mice with overexpression of $\beta_{1}-A R$ and $\beta_{2}-A R$ were generated [56]. Initial observations, performed on young animals, show no cardiac pathology with up to 60 -fold overexpression of $\beta_{2}$-AR [57] - the promising target for restoration in heart failure. Longer observation, however, reveals quite a different picture; both transgenic models, overexpressing $\beta_{1}$-AR [58] or $\beta_{2}$-AR [59] develop cardiomyopathy and heart failure. The same result was obtained with mice overexpressing down-stream signaling molecule for both adrenergic receptors; cardiac stimulatory $\mathrm{G}$ protein alpha subunit-Gs $\alpha[60,61]$ and alpha catalytic subunit $(\mathrm{C} \alpha)$ of PKA [62].
All these studies concluded that selective down regulation of $\beta-A R$ in patients with HF is a compensatory and protective mechanism, shifting paradigm from sympathetic stimulation toward blocking. In the beginning, $\beta$-blockers were introduced as a therapy to control the tachycardia associated with HF which unexpectedly reduced mortality in acute myocardial infarction [63]. Although few trials were conducted in following years, the first large randomized clinical trial showed clear evidence of mortality benefit was released in $1999[64,65]$. Currently three types of $\beta$-blockers classified as $\beta_{1}$-AR selective, non-selective $\beta$-AR blockers and non-selective $\beta / \alpha$-AR blockers are in use. Interestingly, non-selective $\beta / \alpha$-AR blockers like carvedilol result in vasodilatation secondary to $\alpha$-AR blockade lowering aortic pressure and are proving to be superior over more selective blockers [66].

Nowdays we have overall acceptance of HF development is connected with progressive remodeling of cardiac sympathetic response. Although we know how to alleviate consequences of this response, we still do not know enough about the trigger of changes, early signs, risk factors, sex specific dynamic and therapy.

The adrenergic receptors behavior under acute and chronic stress. In 1936 Dr. Hans Selye presented his finding of General Adaptation Syndrome explaining how various nocuous agents (exposure to cold, surgical injury, excessive muscular exercise, sublethal intoxication) produced the same typical response in experimental animals [67]. He described three stages of the syndrome development: the initial one expressed as a general alarm (decrease in size of lymphoid organs and fat tissue, fall of body temperature, formation of erosions in digestive tract), the phase of building up resistance and the phase of exhaustion after a period of a prolonged stress. The article was a cornerstone in the field of neuropsychiatry, kicking up an avalanche of studies and helping to reveal the effect of hormones and stress on the brain function. Today we understand stress as a multi-system response to challenges threatening homeostasis, having bearable or overwhelming allostatic load and potential health consequences [68].

All of the situations like the first jump with parachute (as well as consequent jumps), running in front of an enraged bull, waiting for a big exam, being threaten with a gun, have in common the surge of epinephrine 
and co-released cortisol from adrenal gland into the bloodstream. These two hormones activate responses in multiple organs having adrenergic or cortisol receptors, particularly response of the stress axis, the hypothalamic-pituitary-adrenal (HPA) axis, and sympathetic-adrenal medullary system. The mark of HPA activation is elevation of corticotropin releasing factor (CRF), synthesized by a discrete population of neurons in parvocellular part of the paraventricular nucleus in the hypothalamus and released into hypophyseal-portal circulation [69]. Neuropeptide arginine vasopressin (AVP) is co-released at the same nerve endings. CRF stimulates synthesis and release of adenocorticotropic hormone (ACTH) from the anterior lobe of the pituitary gland while binding of arginine vasopressin to $\mathrm{V} 1 \mathrm{~b}$ pituitary receptors enhance release of ACTH in the system circulation [70]. ACTH induces glucocorticoid production and its release from the adrenal cortex. Besides numerous physiological and metabolic effects (suppression of immune, reproductive and digestive organs, inhibition of growth, glucolysis, proteolysis and lipolysis), glucocorticoids are one of the six known transcriptional activators of epinephrine synthesizing enzyme phenylethanolamine N-methyltransferase (PNMT) [71-73]. This enzyme is confined in its distribution just to the adrenal medulla and adrenalin synthesizing neurons of the brain stem in healthy individuals, consequently producing more epinephrine. At the same time, a parallel track is also being activated; the sympathetic system releases norepinephrine stimulating target organs having adrenergic receptors, including adrenal medulla. Epinephrine regulates its own production by inhibiting PNMT [74]. It is one of many inhibitory loops throughout HPA axis, bringing all players back to basal level.

In between various animal models of stress (foot shock, electric shocks, forced swimming, forced running, etc.) immobilization on wooden board is considered a putative model of posttraumatic stress disorders (PTSD). Single and repeated exposures induce dysregulation of the resting activity of the HPA axis [75], observed as increase in resting corticosterone levels $[76,77]$. Dysregulation of HPA triggers multiple changes in target organs. The transcriptome in the adrenal medulla after acute and chronic stress exposure is very different; the number of transcripts significantly diffe- red in the rat medulla after single immobilization - it was bigger (651 up and 487 down) than after immobilization on six consecutive days (370 up and 195 down) [78]. Transcription factors and cell signaling molecules go through the largest changes accompanied with transcripts related to growth factors, apoptosis, neurosecretion, heat shock proteins, structural proteins, chemokines, cytokines, metabolism and proteases.

Immediate cardiovascular response to raised levels of epinephrine at the beginning of the stress response is increased blood pressure and heart rate, respectively. The heart is very sensitive to the changes of adrenergic levels, because $95 \%$ of norepinephrine released on the sympathetic nerves is being recaptured [79]. In stress response, levels of epinephrine are major drive of cardiac performance. Hence, changes in norepinephrine reuptake mechanism and/or neurotransmitter load would sensitize the heart to arrhythmia development during intense sympathetic activation, as during panic attacks, for example [6].

In a model of foot shock stress Basani reported supersensitivity of isolated rat heart pacemaker to $\beta_{2}$-selective agonists [80] suggesting increased $\beta_{2}$-signaling. At the same time right atria were subsensitive to selective $\beta_{1}$-agonist. Observed remodeling of adrenergic receptors was canceled by treatment with the mifepristone, glucocorticoid receptor antagonist, indicating involvement of glucocorticoid mediated mechanism [81]. Similar experiments repeated on female rats demonstrated more elevated plasma corticosterone in female versus male animals, independent of estrus cycle, the same changes of adrenergic receptors during diestrus and lack of changes in estrus [82]. This data suggests a role of sex steroids at least in remodeling of female heart. Changes in adrenergic receptors also take place in adipose tissue manifested as decreased expression of the $\beta_{1}$ - and $\beta_{3}$-AR accompanied with increase expression of $\beta_{2}$-AR [83] and reflected in altered sensitivity to insulin [84]. While increase of $\beta_{2}$-signaling during stress response could be interpreted as protective because it was directing heart from activation of PKA, $\mathrm{Ca}^{2+}$ overload and apoptosis caused by $\beta_{1}-\mathrm{AR}$, on the other hand, raises insulin resistance in fat tissue, which is a bad strategy on the long term, leading to a «thrifty metabolism». However, recently used fluorescence resonance energy transfer (FRET) microscopy demonst- 
rated particularity in distribution of adrenergic receptors in cardiomyocytes of failing heart [85]. Besides being more expressed, $\beta_{2}$-AR in failing heart are redistributed from their common place at tranverse tubules to the cell crest - compartment of cAMP production reserved for $\beta_{1}$-AR. Final outcome is $\beta_{2}$-AR coupled to different signaling mechanism and behaving like $\beta_{1-}$ $\mathrm{AR}$, also proved in the development of cardiomyopathies in $\beta_{2}$-AR transgenic animals $[59,86]$. To make stress response of the heart even more complicated, different heart regions express different shift in adrenergic receptors; murine right ventricules express decreased level of $\beta_{2}$-AR [87].

The adrenergic receptor remodeling is accompanied by the changes in the level of catecholamine. Elevated urinary concentrations of norepinephrine and epinephrine are observed in patients with posttraumatic stress disorder (PTSD) [88, 89]. Stress elevates the expression of PNMT mRNA [90] in a glucocorticoid dependent manner, especially after repeated immobilization stress, but not only at the adrenal medulla and neurons of the brain steam, but also at sympathetic nerve endings and cardiac tissue [91, 92]. Epinephrine is increased after the first immobilization, while levels of norepinephrine rise after the seventh immobilization [87]. Epinephrine is also found in the samples of blood from coronary sinus, released by the sympathetic nerves of heart in patients with essential hypertension [7] this was considered pathophysiological mechanism in the development of this disease. No association was found between polymorphism of $\beta_{2}-\mathrm{AR}$, the most frequent arterial adrenergic receptor, and hypertension and obesity [93]. However, the gene polymorphism in the rate-limiting enzyme in catecholamine biosynthesis, tyrosine hydroxylase (TH), is connected with stress-induced blood pressure changes [94]. On the other hand, angiotensin II AT1 receptor blockers (ARBs), commonly used in the clinical treatment of arterial hypertension profoundly modify the response to the stress, preventing the peripheral and central sympathetic activation [95]. ARBs, transportable across the bloodbrain barrier, are a potential treatment of stress related and anxiety disorders [96, 97].

In most brain regions $\beta_{1}$-ARs comprise $>80 \%$ of adrenergic receptors [98]. Single exposure to restrained stress significantly decreases levels of $\beta_{1}$-AR mRNA in the hypopthalamus, but repeated exposure brings back to control levels [99].

Right now we do not have any reliable and easy to follow stress-specific marker which could be used in studies of human or animal exposure to different stressors and their different intensity. Animal studies are pointing to significant remodeling of adrenergic receptors in heart and blood vessels in chronic stress, but even in animal models we do not know how to prevent them. Also, most animal studies are short-term, observing changes provoked after consecutive stress exposure, while observations from human studies predict more then a decade or two long progression of cardiac pathology. We are looking not just for an animal model, but also for a study plan which would combine the major risk factors and follow up data on vital functions in a long term study.

Sex specific traits in the stress response and development of heart failure. HPA response is a very expensive effort for an organism and if overengaged has potential consequences [100]. It is often raised in the modern society even in the absence of physiological challenge, driven by conditioning («memory») during anticipation of potential threat [69]. The autonomous nervous system has an interesting feature of isolating some organs and/or recruiting some more than others in general stress response. The heart is just one of the target organs in the stress response, whose engagement depends on individual heritable traits (including sex) and the environment as well.

The heart rhythm transcriptome genes encoding adrenergic receptors, connexins, cadherins, plakophilins, ankyrins, ion channels and transporters have significant heart chamber sex differences observed in the rat animal model [101]. Differences become particularly prominent in knockout models challenged by physiological ligand, agonist and antagonist of various receptors participating in stress response [102].

Environmental and sex-specific genetic factors are reflected on the pathology: prevalence of hypertension in Western society is higher in men aged 30-45 years than in women of similar age. On the other hand prevalence of hypertension in women after this age increases to levels similar to or exceeds those in men [103-105]. Reverse man versus women epidemiology is observed in vasomotor disorders like Raynaud's disease, postu- 
ral orthostatic tachycardia syndrome and vasomotor symptoms (hot flashes) of menopause and migraine [106]. In both human and animal heart pathology differences is connected with estrogen levels [107-109].

Because women develop manifestation of coronary disease 10 years later then men, on average, and present with myocardial infarction 20 years later [110], general preconception is still how cardiovascular disease (CVD) is not a leading cause of mortality in women. The consequences of this misconception are numerous: the two-thirds of women, who died suddenly, had unrecognized CVD symptoms, $35 \%$ of heart attacks in women are believed to go unnoticed or unreported, women present later and are more sick at the time of diagnosis, they are less likely to undergo interventional cardiology, undergo cardiac rehabilitation and return to work after the first heart attack - which they are less likely to live through [111]. Women with acute coronary disease are more likely to present atypical symptoms: vomiting, abnormal pain location, nausea, dizziness and fatigue. The pathophysiology of HF is also different in men and women: women more frequently develop diastolic HF with preserved left ventricular function and normal ejection fraction accompanied with prolonged history of arterial hypertension and comorbidities [112, 113], men more frequently have systolic HF because of coronary artery disease [114]. Pressure overload, arterial hypertension, diabetes and aging itself initiate myocardial hypertrophy. The hypertrophy generates alterations in cardiac geometry, referred as ventricular remodeling, measured by transthoracic echocardiography (two-dimensional or three-dimensional) and expressed as left ventricular (LV) volume, mass, sphericity index or LV mass/volume. The first stage of hypertrophy is adaptive response to stress due to increase of cardiomyocytes size and deposition of extracellular matrix [115]. Further progression of hypertrophy becomes maladaptive if accompanied with fibrosis (involving collagen deposition) and apoptosis. Male hearts develop more easily pathological hypertrophy, while female ventricular remodeling follows the pattern of diastolic HF having a greater risk of adverse outcome as baseline ejection fraction is decreasing $[113,116]$.

Chronic hypertension induced ventricular hypertrophy, left ventricular fibrosis and action potential prolongation is observed in animal models of both aging male and female Spontaneosly Hypertensive Rats (SHR) [117]. Male animals from 15 months of age develop left ventricular thinning, systolic and diastolic dysfunction, which is not present in females at the same age. In the mouse model of pressure overload by transverse aortic constriction, males show more hypertrophy than females and females develop concentric while males develop eccentric hypertrophy [118]. Induction of matrix-related genes and a repression of mitochondrial genes in maladaptive stress response are attenuated in estrogen receptor $\beta$ knockout mice pointing to molecular mechanism of estrogen protection. Estrogen therapy in male G $\alpha$ q transgenic mice prevent HF by inhibition of apoptosis-regulated signaling kinase-1 [119].

Women and men respond differently to chronic HF therapies, tailored to better fit to male than female pathology [120]. Women benefit more from angiotensin receptor blockers, while men benefit more from angiotensin converting enzyme inhibitor [121]. Low dose of estrogen attenuate structural and functional remodeling in an animal model of HF [122]. Contrarily, estrogen treated female rats have a greater postmyocardial infarction survival [123].

Also, estrogen did not improve ischemia and endothelial function in randomized controlled trials in postmenopausal women [124]. In survival studies, women had advantage in advance HF if presented with nonischemic etiology [120].

The role of stress in CVD development is not fully investigated. Sexual dismorphism in the stress response, especially its relation to female hormonal cycle, has been observed in animal models and in humans [125, 126]. Stress induces different changes of adrenergic receptors and their signaling pathways. While all subtypes of $\alpha_{1}$-AR decrease in female mice, it happens just to $\alpha_{1 \mathrm{~A}}$-AR in a CRH gene knockout, suggesting the role of $\mathrm{CRH}$ in down-regulation of others. However, $\beta_{1}$-AR decreases in male mice, but remains stable in female mice. Also, while the ability of $\alpha_{2}$-AR agonist to inhibit insulin secretion was attenuated in male insulin receptor substrate 2 knockout animals, female animal developed mild obesity and progressed less rapidly to diabetes under adrenergic stimulation [127]. Adrenergic receptors and their down-stream signaling molecules exert a variety of effects and these molecules are good 
candidate genes in gene polymorphism studies dealing with sex-specific pathology. The polymorphism in the nuclear receptor genes, like glucocorticoid receptor, was documented as a significant sex specific factor in rising stress response to psychosocial stimuli [128]. Also, the sex specific pathway of cardioprotection mediated by estrogen receptors include transcription factor myocyte enhancer factor 2 and class II histone deacetylases, potential targets in sex specific therapy [129]. Polymorphism in the $\beta_{1}-\mathrm{AR}$ and $\beta_{3}$-AR increases cardiovascular risk in women, more to microvascular pathology than to obstructive coronary disease [130].

Difference in stress-response reactions is noticed in the peripheral and central nervous systems. Functional brain imaging studies of central stress response circuitry (amygdale, hypothalamus, hippocampus, brainstem, orbitofrontal cortex, medial prefrontal cortex and anterior cingulated gyrus) found the most prominent differences between men and women during early follicular phase [126]. Activation of central stress response circuitry somehow predisposed women for development of more adverse effects; about twice as many women as men would develop PTSD, under the same exposure to trauma [131].

Also symptoms of further exacerbation are diferent, while anxiety is better predictor of PTSD in men, depression is found in women [132]. Psychosocial variables were recently associated with morbidity and mortality in CVD patients [133]. Psychosocial stress and depression might have role in accelerated aging [134]. Telomere length is a marker of biological aging and presence of stressor. A telomerase deficient mouse model is recently used in HF studies [135]. Emotional/cognitive symptom cluster composed of worrying, feeling depressed and expressing cognitive problems predicts a high risk for a cardiac event [136]. Insomnia is a risk factor and symptom of stress, depression and anxiety [137], highly prevalent in patients with chronic heart disease [138].

Besides all indirect links between stress and cardiac disease in humans, Tako-Tsubo syndrome, firstly described by Sato et al in 1990 (Japan), directly links excessive sympathetic stimulation triggered by intense psychological or physical stress and acute cardiomyopathy in the absence of arterosclerotic coronary artery disease $[139,140]$.
Stress is a multi organ disease. The heart is just one organ affected after years, even decades of increased sympathetic activity. Additional risk factors, genetic, metabolic, socioeconomic and environmental bring a different load on homeostatic mechanisms. The development of HF differs between male and female, this is visible in the stress induced heart remodeling. Close observation of the differences will bring us closer to sex-specific therapy in the near future.

\section{М. Хеффер, Л. Зибар, Б. Вильетич, 3. Макарович \\ Роль стресу у серцевій патології - основа міжстатевих патофізіологічгих розбіжностей \\ Резюме}

За останне століття сучасне суспільство зазнало багаточисельних змін у способі життя (звичках, харчуванні, навантаженнях, фізичній активності), а також під впливом чинників довкілля. Як біологічний вид ми не дуже добре адаптувалися до нових умов. Вищі рівні гормонів стресу спричиняють різні ефекти, поступово змінюється чутливість адренергічних, глюкокортикоїдних і інсулінових рещепторів. Усі иі зміни взаємопов 'язані і залежно від генетичних і екологічних факторів призводять до таких метаболічних синдромів, як ожиріння, иукровий діабет, сериева недостатність тощо. Оскільки відповідь на стрес залежить $і$ від статі, потрібно враховувати можливу різницю у патофізіології сериевої недостатності у чоловіків і жінок. Протягом багатьох років функиії вегетативної нервової системи невірно трактувалися сучасною медициною, щео відбилося на терапії сериевої недостатності і $і$ пертензії. Вплив стресу на сериеву функиію у перід до і після менопаузи різниться. У жінок у постменопаузі значно підвищується ризик сериево-судинних захворювань, який визначається зниженням захисної функиії жіночого гормонального ииклу. Глибше вивчення молекулярних механізмів діїядерних реиепторів стероїдних гормонів, факторів транскрипиії, які беруть участь у ремоделюванні серия, перехресних адренергічних сигнальних иляхів та їхніх ефекторних молекул призведе до постановки нових задач для гендер-специфічної терапії.

Ключові слова: сериева недостатність, стрес, адренергічні рецептори, статева специфічність.

М. Хеффер, Л. Зибар, Б. Вильетич, 3. Макарович

Роль стресса в сердечной патологии - основа патофизиологических различий между полами

Резюме

За последнее столетие современное общество претерпело многочисленные изменения в образе жизни (привычках, способе питании, нагрузках, физической активности), а также под влиянием факторов окружающей среды. Как биологический вид мы не очень хорошо адаптировались к новым условиям. Более высокие уровни гормонов стресса приводят к различным эффектам, постепенно меняется чувствительность адренергических, глюкокортикоидных и инсулиновых реиепторов. Все эти изменения взаимосвязаны и в зависимости от генетической и экологических факторов приводят к таким метаболи- 
ческим синдромам, как ожирение, сахарный диабет, сердечная недостаточность и др. Поскольку ответ на стресс зависит и от пола, нужно учитывать возможную разницу в патофизиологии сердечной недостаточности у мужчин и женщин. В течение многих лет функиии вегетативной нервной системы неверно трактовались современной медициной, что отразилось на терапии сердечной недостаточности и гипертензии. Влияние стресса на сердечную функиию в период до и после менопаузы различается. У женщин в постменопаузе значительно повышается риск сердечно-сосудистых заболеваний, определяемый снижением защитной функиии женского гормонального ичикла. Более углубленное изучение молекулярных механизмов действия ядерных рецепторов стероидных гормонов, факторов транскрипции, участвующих в ремоделировании сердия, перекрестных адренергических сигнальных путей и их эффекторных молекул приведет к постановке новых задач для гендер-специифической терапии.

Ключевые слова: сердечная недостаточность, стресс, адренергические рецепторы, половая специфичность.

\section{REFERENCES}

1. Armour J. A. Potential clinical relevance of the «little brain» on the mammalian heart // Exp. Physiol.-2008.-93, N 2.- P. 165176.

2. Cheng Z., Powley T. L., Schwaber J. S., Doyle F. J. 3rd. Vagal afferent innervation of the atria of the rat heart reconstructed with confocal microscopy // J. Comp. Neurol.-1997.-381, N 1.P. 1-17.

3. Dhein S., van Koppen C. J., Brodde O. E. Muscarinic receptors in the mammalian heart // Pharmacol. Res.-2001.-44, N 3.P. 161-182.

4. MyslivecekJ., Novakova M., Palkovits M., Krizanova O., Kvetnansky $R$. Distribution of mRNA and binding sites of adrenoceptors and muscarinic receptors in the rat heart // Life Sci.2006.-79, N 2.-P. 112-120.

5. Wang H., Lu Y.Wang Z. Function of cardiac M3 receptors // Auton. Autacoid Pharmacol.-2007.-27, N 1.-P. 1-11.

6. Wilkinson D. J., Thompson J. M., Lambert G. W., Jennings G. L., Schwarz R. G., Jefferys D., Turner A. G., Esler M. D. Sympathetic activity in patients with panic disorder at rest, under laboratory mental stress, and during panic attacks // Arch. Gen. Psychiatry.-1998.-55, N 6.-P. 511-520.

7. Rumantir M. S., Jennings G. L., Lambert G. W., Kaye D. M., Seals $D$. R., Esler M. D. The «adrenaline hypothesis» of hypertension revisited: evidence for adrenaline release from the heart of patients with essential hypertension // J. Hypertens.-2000.18, N 6.-P. 717-723.

8. Morris M. J., Cox H. S., Lambert G. W., Kaye D. M., Jennings G. L., Meredith I. T., Esler M. D. Region-specific neuropeptide Y overflows at rest and during sympathetic activation in humans // Hypertension.-1997.-29, Pt 1.-P. 137-143.

9. Esler M., Kaye D. Measurement of sympathetic nervous system activity in heart failure: the role of norepinephrine kinetics // Heart Fail. Rev.-2000.-5, N 1.-P. 17-25.

10. WolffD. W., Dang H. K., Liu M. F., Jeffries W. B., Scofield M. A. Distribution of alpha 1-adrenergic receptor mRNA species in rat heart // J. Cardiovasc. Pharmacol.-1998.-32, N 1.-P. 117-122.

11. Jensen B. C., Swigart P. M., Laden M. E., DeMarco T., Hoopes C., Simpson P. C. The alpha-1D is the predominant alpha-1adrenergic receptor subtype in human epicardial coronary arteries // J. Am. Coll. Cardiol.-2009.-54, N 13.-P. 1137-1145.
12. Bylund D. B. Subtypes of alpha 1- and alpha 2-adrenergic receptors // FASEB J.-1992.-6, N 3.-P. 832-839.

13. Gauthier C., Tavernier G., Charpentier F., Langin D., Le Marec $H$. Functional beta3-adrenoceptor in the human heart // J. Clin. Invest.-1996.-98, N 2.-P. 556-562.

14. Ito M., Grujic D., Abel E. D., Vidal-Puig A., Susulic V. S., Lawitts J., Harper M. E., Himms-Hagen J., Strosberg A. D., Lowell $B$. B. Mice expressing human but not murine beta3-adrenergic receptors under the control of human gene regulatory elements // Diabetes.-1998.-47, N 9.-P. 1464-1471.

15. Preitner F., Muzzin P., Revelli J. P., Seydoux J., Galitzky J., Berlan M., Lafontan M., Giacobino J. P. Metabolic response to various beta-adrenoceptor agonists in beta3-adrenoceptor knockout mice: evidence for a new beta-adrenergic receptor in brown adipose tissue // Br. J. Pharmacol.-1998.-124, N 8.P. 1684-1688.

16. Granneman J. G. The putative beta 4-adrenergic receptor is a nvel state of the beta1-adrenergic receptor// Am. J. Physiol. Endocrinol. Metab.-2001.-280, N 2.-P. E199-202.

17. Santos I. N., Spadari-Bratfisch R. C. Stress and cardiac beta adrenoceptors // Stress.-2006.-9, N 2.-P. 69-84.

18. Wang W., Zhu W., Wang S., Yang D., Crow M. T., Xiao R. P., Cheng $H$. Sustained betal-adrenergic stimulation modulates cardiac contractility by $\mathrm{Ca}^{2+} /$ calmodulin kinase signaling pathway // Circ. Res.-2004.-95, N 8.-P. 798-806.

19. Curran J., Hinton M. J., Rios E., Bers D. M., Shannon T. R. Betaadrenergic enhancement of sarcoplasmic reticulum calcium leak in cardiac myocytes is mediated by calcium/calmodulin-dependent protein kinase // Circ. Res.-2007.-100, N 3.-P. 391-398.

20. Freestone N. S., Heubach J. F., Wettwer E., Ravens U., Brown D., Kaumann A. J. Beta4-adrenoceptors are more effective than betal-adrenoceptors in mediating arrhythmic $\mathrm{Ca}^{2+}$ transients in mouse ventricular myocytes // Naunyn Schmiedebergs Arch. Pharmacol.-1999.-360, N 4.-P. 445-456.

21. Zhu W. Z., Zheng M., Koch W. J., Lefkowitz R. J., Kobilka B. K., Xiao R. P. Dual modulation of cell survival and cell death by beta(2)-adrenergic signaling in adult mouse cardiac myocytes // Proc. Natl Acad. Sci. USA.-2001.-98, N 4.-P. 1607-1612.

22. Pott C., Brixius K., Bundkirchen A., Bolck B., Bloch W., Steinritz D., Mehlhorn U., Schwinger R. H. The preferential beta3adrenoceptor agonist BRL 37344 increases force via beta1-/ beta2-adrenoceptors and induces endothelial nitric oxide synthase via beta3-adrenoceptors in human atrial myocardium // Br. J. Pharmacol.-2003.-138, N 3.-P. 521-529.

23. Sartiani L., De Paoli P., Stillitano F., Aimond F., Vassort G., Mugelli A., Cerbai E. Functional remodeling in post-myocardial infarcted rats: focus on beta-adrenoceptor subtypes // J. Mol. Cell. Cardiol.-2006.-40, N 2.-P. 258-266.

24. Shen Y. T., Cervoni P., Claus T., Vatner S. F. Differences in beta 3 -adrenergic receptor cardiovascular regulation in conscious primates, rats and dogs // J. Pharmacol. Exp. Ther.-1996.-278, N 3.-P. 1435-1443.

25. Kaumann $A$. J. Is there a third heart beta-adrenoceptor? // Trends Pharmacol. Sci.-1989.-10, N 8.-P. 316-320.

26. Kaumann A. J., Lynham J. A. Stimulation of cyclic AMP-dependent protein kinase in rat atria by (-)-CGP 12177 through an atypical beta-adrenoceptor // Br. J. Pharmacol.-1997.-120, N 7.-P. 1187-1189.

27. Hopkins D. A., Armour J. A. Ganglionic distribution of afferent neurons innervating the canine heart and cardiopulmonary nerves // J. Auton. Nerv. Syst.-1989.-26, N 3.-P. 213-222.

28. Quigg $M$. Distribution of vagal afferent fibers of the guinea pig heart labeled by anterograde transport of conjugated horseradish peroxidase // J. Auton. Nerv. Syst.-1991.-36, N 1.-P. 13-24. 
29. Guic M. M., Kosta V., Aljinovic J., Sapunar D., Grkovic I. Characterization of spinal afferent neurons projecting to different chambers of the rat heart // Neurosci. Lett.-2010.-469, N 3.P. 314-318.

30. Smith H. J., Oriol A., Morch J., McGregor M. Hemodynamic studies in cardiogenic shock: treatment with isoproterenol and metaraminol // Circulation.-1967.-35, N 6.-P. 1084-1091.

31. Bayram M., De Luca L., Massie M. B., Gheorghiade M. Reassessment of dobutamine, dopamine, and milrinone in the management of acute heart failure syndromes // Am. J. Cardiol.2005.-96, N 6A.-P. 47G-58G.

32. van de Borne P., Oren R., Somers V. K. Dopamine depresses minute ventilation in patients with heart failure // Circulation.1998.-98, N 2.-P. 126-131.

33. Tuttle R. R., Mills J. Dobutamine: development of a new catecholamine to selectively increase cardiac contractility // Circ. Res.-1975.-36, N 1.-P. 185-196.

34. Lambertz H., Meyer J., Erbel R. Long-term hemodynamic effects of prenalterol in patients with severe congestive heart failure // Circulation.-1984.-69, N 2.-P. 298-305.

35. The xamoterol in severe heart failure study group. Xamoterol in severe heart failure // The Lancet.-1990.-336, N 8706.-P. 1-6.

36. O'Connor C. M., Gattis W. A., Uretsky B. F., Adams K. F. Jr., McNulty S. E., Grossman S. H., McKenna W. J., Zannad F., Swedberg K., Gheorghiade M., Califf R. M. Continuous intravenous dobutamine is associated with an increased risk of death in patients with advanced heart failure: insights from the Flolan International Randomized Survival Trial (FIRST) // Am. Heart J.-1999.-138, N 1.-P. 78-86.

37. Felker G. M., Benza R. L., Chandler A. B., Leimberger J. D., Cuffe M. S., Califf R. M., Gheorghiade M., O'Connor C. M. Heart failure etiology and response to milrinone in decompensated heart failure: results from the OPTIME-CHF study // J Am. Coll. Cardiol.-2003.-41, N 6.-P. 997-1003.

38. Metra M., Eichhorn E., Abraham W. T., Linseman J., Bohm M., Corbalan R., DeMets D., De Marco T., Elkayam U., Gerber M., Komajda M., Liu P., Mareev V., Perrone S. V., Poole-Wilson P., Roecker E., Stewart J., Swedberg K., Tendera M., Wiens B., Bristow $M$. R. Effects of low-dose oral enoximone administration on mortality, morbidity, and exercise capacity in patients with advanced heart failure: the randomized, double-blind, placebo-controlled, parallel group ESSENTIAL trials // Eur. Heart J.-2009.-30, N 24.-P. 3015-3026.

39. Yamaguchi A., Tanaka M., Naito K., Kimura C., Kobinata T., Okamura H., Ino T., Adachi $H$. The efficacy of intravenous milrinone in left ventricular restoration // Ann. Thorac. Cardiovasc. Surg.-2009.-15, N 4.-P. 233-238.

40. Chidsey C. A., Braunwald E., Morrow A. G., Mason D. T. Myocardial norepinephrine concentration in man - effects of reserpine and of congestive heart failure // New Engl. J. Med.-1963.269, N 13.-P. 653-658.

41. Allman K. C., Wieland D. M., Muzik O., Degrado T. R., Wolfe E. $R$. Jr., Schwaiger M. Carbon-11 hydroxyephedrine with positron emission tomography for serial assessment of cardiac adrenergic neuronal function after acute myocardial infarction in humans // J. Am. Coll. Cardiol.-1993.-22, N 2.-P. 368-375.

42. Bristow M. R., Ginsburg R., Umans V., Fowler M., Minobe W., Rasmussen R., Zera P., Menlove R., Shah P., Jamieson S., Stinson E. B. Beta 1- and beta 2-adrenergic-receptor subpopulations in nonfailing and failing human ventricular myocardium: coupling of both receptor subtypes to muscle contraction and selective beta 1-receptor down-regulation in heart failure // Circ. Res.-1986.-59, N 3.-P. 297-309.
43. Brodde O. E. Pathophysiology of the beta-adrenoceptor system in chronic heart failure: consequences for treatment with agonists, partial agonists or antagonists? // Eur. Heart J.-1991.-12, Suppl F.-P. 54-62.

44. Bristow M. R., Hershberger R. E., Port J. D., Minobe W., Rasmussen $R$. Beta 1 - and beta 2 -adrenergic receptor-mediated adenylate cyclase stimulation in nonfailing and failing human ventricular myocardium // Mol. Pharmacol.-1989.-35, N 3.P. 295-303.

45. Bristow M. R., Hershberger R. E., Port J. D., Gilbert E. M., Sandoval A., Rasmussen R., Cates A. E., Feldman A. M. Betaadrenergic pathways in nonfailing and failing human ventricular myocardium // Circulation.-1990.-82, 2 Suppl.-P. I12-25.

46. Bristow M. R., Anderson F. L., Port J. D., Skerl L., Hershberger R. E., Larrabee P., O'Connell J. B., Renlund D. G., Volkman K., Murray J., Feldman A. M. Differences in beta-adrenergic neuroeffector mechanisms in ischemic versus idiopathic dilated cardiomyopathy // Circulation.-1991.-84, N 3.-P. 1024-1039.

47. Cohn J. N., Levine T. B., Olivari M. T., Garberg V., Lura D., Francis G. S., Simon A. B., Rector T. Plasma norepinephrine as a guide to prognosis in patients with chronic congestive heart failure // New Engl. J. Med.-1984.-311, N 13.-P. 819-823.

48. Levine T. B., Francis G. S., Goldsmith S. R., Simon A. B., Cohn $J$. N. Activity of the sympathetic nervous system and reninangiotensin system assessed by plasma hormone levels and their relationship to hemodynamic abnormalities in congestive heart failure // Am. J. Cardiol.-1982.-49, N 7.-P. 1659-1666.

49. Hasking G. J., Esler M. D., Jennings G. L., Burton D., Johns J. A., Korner P. I. Norepinephrine spillover to plasma in patients with congestive heart failure: evidence of increased overall and cardiorenal sympathetic nervous activity // Circulation.-1986.73, N 4.-P. 615-621.

50. Kaye D. M., Lefkovits J., Jennings G. L., Bergin P., Broughton A., Esler M. D. Adverse consequences of high sympathetic nervous activity in the failing human heart // J. Am. Coll. Cardiol.1995.-26, N 5.-P. 1257-1263.

51. Rundqvist B., Elam M., Bergmann-Sverrisdottir Y., Eisenhofer $G$., Friberg $P$. Increased cardiac adrenergic drive precedes generalized sympathetic activation in human heart failure // Circulation.-1997.-95, N 1.-P. 169-175.

52. Meredith I. T., Broughton A., Jennings G. L., Esler M. D. Evidence of a selective increase in cardiac sympathetic activity in patients with sustained ventricular arrhythmias // New Engl. J. Med.-1991.-325, N 9.-P. 618-624.

53. Smith-White M. A., Herzog H., Potter E. K. Role of neuropeptide Y Y(2) receptors in modulation of cardiac parasympathetic neurotransmission // Regul. Pept.-2002.-103, N 2-3.-P. 105111

54. Patel K. P., Zhang P. L., Krukoff T. L. Alterations in brain hexokinase activity associated with heart failure in rats // Am. J. Physiol.-1993.-265, N 4.-P. R923-R928.

55. Patel K. P., Zhang K. Neurohumoral activation in heart failure: role of paraventricular nucleus // Clin. Exp. Pharmacol. Physiol.-1996.-23, N 8.-P. 722-726.

56. Milano C. A., Allen L. F., Rockman H. A., Dolber P. C., McMinn T. R., Chien K. R., Johnson T. D., Bond R. A., Lefkowitz R. J. Enhanced myocardial function in transgenic mice overexpressing the beta 2-adrenergic receptor // Science.-1994.-264, N 5158.P. 582-586

57. Liggett S. B., Tepe N. M., Lorenz J. N., Canning A. M., Jantz T. D., Mitarai S., Yatani A., Dorn G. W., 2nd. Early and delayed consequences of beta(2)-adrenergic receptor overexpression in mouse hearts: critical role for expression level // Circulation.2000.-101, N 14.-P. 1707-1714. 
58. Engelhardt S., Hein L., Wiesmann F., Lohse M. J. Progressive hypertrophy and heart failure in beta1-adrenergic receptor transgenic mice // Proc. Natl Acad. Sci. USA.-1999.-96, N 12.P. 7059-7064.

59. Du X.-J., Gao X.-M., Wang B., Jennings G. L., Woodcock E. A., Dart A. M. Age-dependent cardiomyopathy and heart failure phenotype in mice overexpressing $\beta_{2}$-adrenergic receptors in the heart // Cardiovasc. Res.-2000.-48, N 3.-P. 448-454

60. Iwase M., Uechi M., Vatner D. E., Asai K., Shannon R. P., Kudej R. K., Wagner T. E., Wight D. C., Patrick T. A., Ishikawa Y. Homcy C. J., Vatner S. F. Cardiomyopathy induced by cardiac Gs alpha overexpression // Am. J. Physiol.-1997.-272, N 1.P. H585-589.

61. Lader A. S., Xiao Y.-F., Ishikawa Y., Cui Y., Vatner D. E., Vatner S. F., Homcy C. J., Cantiello H. F. Cardiac Gsalpha overexpression enhances L-type calcium channels through an adenylyl cyc lase independent pathway // Proc. Natl Acad. Sci. USA.-1998.95, N 16.-P. 9669-9674.

62. Antos C. L., Frey N., Marx S. O., Reiken S., Gaburjakova M., Richardson J. A., Marks A. R., Olson E. N. Dilated cardiomyopathy and sudden death resulting from constitutive activation of protein kinase A // Circ. Res.-2001.-89, N 11.-P. 997-1004.

63. Waagstein F., Hjalmarson A. C., Wasir H. S. Apex cardiogram and systolic time intervals in acute myocardial infarction and effects of practolol // Br. Heart. J.-1974.-36, N 11.-P. 11091121.

64. Segev A., Mekori Y. A. The cardiac insufficiency bisoprolol study II // Lancet.-1999.-353, N 9161.-P. 1361.

65. Poole-Wilson P. A. The cardiac insufficiency bisoprolol study II // Lancet.-1999.-353, N 9161.-P. 1360-1361.

66. Poole-Wilson P. A., Swedberg K., Cleland J. G., Di Lenarda A., Hanrath P., Komajda M., Lubsen J., Lutiger B., Metra M., Remme W. J., Torp-Pedersen C., Scherhag A., Skene A. Comparison of carvedilol and metoprolol on clinical outcomes in patients with chronic heart failure in the Carvedilol Or Metoprolol European Trial (COMET): randomised controlled trial // Lancet.2003.-362, N 9377.-P. 7-13.

67. Selye $H$. A syndrome produced by diverse nocuous agents // Nature.-1936.-138, N 3479.- P. 32.

68. Day T. A. Defining stress as a prelude to mapping its neurocircuitry: no help from allostasis // Prog. Neuropsychopharmacol. Biol. Psychiatry.-2005.-29, N 8.-P. 1195-1200.

69. Herman J. P., Figueiredo H., Mueller N. K., Ulrich-Lai Y., Ostrander M. M., Choi D. C., Cullinan W. E. Central mechanisms of stress integration: hierarchical circuitry controlling hypothalamo-pituitary-adrenocortical responsiveness // Front. Neuroendocrinol.-2003.-24, N 3.-P. 151-180.

70. Tanoue A., Ito S., Honda K., Oshikawa S., Kitagawa Y., Koshimizu T. A., Mori T., Tsujimoto $G$. The vasopressin V1b receptor critically regulates hypothalamic-pituitary-adrenal axis activity under both stress and resting conditions // J. Clin. Invest.2004.-113, N 2.-P. 302-309.

71. Ross M. E., Evinger M. J., Hyman S. E., Carroll J. M., Mucke L., Comb M., Reis D. J., Joh T. H., Goodman H. M. Identification of a functional glucocorticoid response element in the phenylethanolamine $\mathrm{N}$-methyltransferase promoter using fusion genes introduced into chromaffin cells in primary culture // J. Neurosci.1990--10, N 2.-P. 520-530.

72. Tai T. C., Claycomb R., Her S., Bloom A. K., Wong D. L. Glucocorticoid responsiveness of the rat phenylethanolamine N-methyltransferase gene // Mol. Pharmacol.-2002.-61, N 6.P. 1385-1392.

73. Wong D. L., Tai T. C., Wong-Faull D. C., Claycomb R., Kvetna$n s k y$. Adrenergic responses to stress: transcriptional and post-transcriptional changes // Ann. N. Y. Acad. Sci.-2008.1148, N 1.-P. 249-256.

74. Fuller R. W., Hunt J. M. Inhibition of phenethanolamine N-methyl transferase by its product, epinephrine // Life Sci.-1967.-6, N 10.-P. 1107-1112.

75. Marti O., Gavalda A., Jolin T., Armario A. Effect of regularityof exposure to chronic immobilization stress on the circadian pattern of pituitary adrenal hormones, growth hormone, and thyroid stimulating hormone in the adult male rat // Psychoneuroendocrinology.-1993.-18, N 1.-P. 67-77.

76. Ottenweller J. E., Servatius R. J., Natelson B. H. Repeated stress persistently elevates morning, but not evening, plasma corticosterone levels in male rats // Physiol. Behav.-1994.-55, N 2.P. 337-340.

77. Fleshner M., Deak T., Spencer R. L., Laudenslager M. L., Watkins L. R., Maier S. F. A long-term increase in basal levels of corticosterone and a decrease in corticosteroid-binding globulin after acute stressor exposure // Endocrinology.-1995.-136, N 12.-P. 5336-5342.

78. Liu X., Serova L., Kvetnansky R., Sabbah E. L. Identifying the stress trancriptome in the adrenal medulla following acute and repeated immobilization // Ann.N. Y. Acad. Sci.-2008.-1148.P. 1-28.

79. Eisenhofer G., Friberg P., Rundqvist B., Quyyumi A. A., Lambert G., Kaye D. M., Kopin I. J., Goldstein D. S., Esler M. D. Cardiac sympathetic nerve function in congestive heart failure // Circulation.-1996.-93, N 9.-P. 1667-1676.

80. Bassani R. A., de Moraes $S$. Effects of repeated footshock stress on the chronotropic responsiveness of the isolated pacemaker of the rat: role of beta-2 adrenoceptors // J. Pharmacol. Exp. Ther.1988.-246, N 1.-P. 316-321.

81. Rahnemaye F., Nourani R., Spadari R. C., De Moraes S. Footshock stress-induced supersensitivity to isoprenaline in the isolated pacemaker of the rat: effect of the compounds RU-38486 and RU-28362 // Gen. Pharmacol.-1992.-23, N 4.-P. 787-791.

82. Marcondes F. K., Vanderlei L. C. M., Lanza L. L. B., SpadariBratfisch R. C. Stress-induced subsensitivity to catecholamines depends on the estrous cycle // Can. J. Physiol. Pharmacol.1996.-74, N 6.-P. 663-699.

83. Farias-Silva E., Grassi-Kassisse D. M., Wolf-Nunes V., Spadari-Bratfisch $R$. C. Stress-induced alteration in the lipolytic response to beta-adrenoceptor agonists in rat white adipocytes // J. Lipid. Res.-1999.-40, N 9.-P. 1719-1727.

84. Farias-Silva E., Sampaio-Barros M. M., Amaral M. E., Carneiro E. M., Boschero A. C., Grassi-Kassisse D. M., Spadari-Bratfisch $R$. C. Subsensitivity to insulin in adipocytes from rats submitted to foot-shock stress // Can. J. Physiol. Pharmacol.2002.-80, N 8.-P. 783-789.

85. Nikolaev V. O., Moshkov A., Lyon A. R., Miragoli M., Novak P., Paur H., Lohse M. J., Korchev Y. E., Harding S. E., Gorelik J. Beta2-adrenergic receptor redistribution in heart failure changes cAMP compartmentation // Science.-2010.-327, N 5973.P. 1653-1657.

86. Peter P. S., Brady J. E., Yan L., Chen W., Engelhardt S., Wang Y., Sadoshima J., Vatner S. F., Vatner D. E. Inhibition of p38 alpha MAPK rescues cardiomyopathy induced by overexpressed beta 2-adrenergic receptor, but not beta 1-adrenergic receptor // J. Clin. Invest.-2007.-117, N 5.-P. 1335-1343.

87. MyslivecekJ., Tillinger A., Novakova M., Kvetnansky R. Regulation of adrenoceptor and muscarinic receptor gene expression after single and repeated stress // Ann. N. Y. Acad. Sci.-2008.1148, N 1.-P. 367-376.

88. Southwick S. M., Bremner J. D., Rasmusson A., Morgan C. A., 3rd, Arnsten A., Charney D. S. Role of norepinephrine in the pa- 
thophysiology and treatment of posttraumatic stress disorder // Biol. Psychiatry.-1999.-46, N 9.-P. 1192-1204.

89. Yehuda R., Siever L. J., Teicher M. H., Levengood R. A., Gerber $D$. K., Schmeidler J., Yang R. K. Plasma norepinephrine and 3methoxy-4-hydroxyphenylglycol concentrations and severity of depression in combat posttraumatic stress disorder and major depressive disorder // Biol. Psychiatry.-1998.-44, N 1.-P. 5663.

90. Sabban E. L., Kvetnansky R. Stress-triggered activation of gene expression in catecholaminergic systems: dynamics of transcriptional events // Trends Neurosci.-2001.-24, N 2.-P. 91-98.

91. Krizanova O., Micutkova L., Jelokova J., Filipenko M., Sabban $E$., Kvetnansky $R$. Existence of cardiac PNMT mRNA in adult rats: elevation by stress in a glucocorticoid-dependent manner // Am. J. Physiol.-2001.-281, N 3.-P. H1372-1379.

92. Kvetnansky R., Kubovcakova L., Tillinger A., Micutkova L., Krizanova O., Sabban E. L. Gene expression of phenylethanolamine N-methyltransferase in corticotropin-releasing hormone knockout mice during stress exposure // Cell. Mol. Neurobiol.2006.-26, N 4-6.-P. 735-754.

93. Galletty F., Iacone R., Ragone E., Russo O., Della Valle E., Siani A., Barba G., Farinaro E., Strazzullo V., Strazzullo P. Lack of association between polymorphism in the beta2-adrenergic receptor gene, hypertension and obesity in the Olivetti heart study // Am. J. Hypertens.-2004.-17, N 8.-P. 718-720.

94. Rao F., Zhang L., Wessel J., Zhang K., Wen G., Kennedy B. P., Rana B. K., Das M., Rodriguez-Flores J. L., Smith D. W., Cadman P. E., Salem R. M., Mahata S. K., Schork N. J., Taupenot L., Ziegler M. G., O'Connor D. T. Tyrosine hydroxylase, the rate-limiting enzyme in catecholamine biosynthesis: discovery of common human genetic variants governing transcription, autonomic activity, and blood pressure in vivo // Circulation.-2007.116, N 9.-P. 993-1006.

95. Armando I., Volpi S., Aguilera G., Saavedra J. M. Angiotensin II AT1 receptor blockade prevents the hypothalamic corticotropin-releasing factor response to isolation stress // Brain Res.2007.-1142.-P. 92-99.

96. Saavedra J. M., Benicky J. Brain and peripheral angiotensin II play a major role in stress // Stress.-2007.-10, N 2.-P. 185-193.

97. Keck M. E., Holsboer F. Hyperactivity of CRH neuronal circuits as a target for therapeutic interventions in affective disorders // Peptides.-2001.-22, N 5.-P. 835-844.

98. Minneman K. P., Hegstrand L. R., Molinoff P. B. Simultaneous determination of beta- 1 and beta-2-adrenergic receptors in tissues containing both receptor subtypes // Mol. Pharmacol.1979.-16, N 1.-P. 34-46.

99. Zhang K., Komori T., Miyahara S., Yamamoto M., Matsumoto T., Okazaki $Y$. Effect of single and repeated restraint stresses on the expression of beta(1)-adrenoceptor mRNA in the rat hypothalamus and midbrain // Neuropsychobiology.-2002.-46, N 3.-P. 121-124.

100. McEwen B. S. Stress, adaptation, and disease: Allostasis and allostatic load // Ann. N. Y. Acad. Sci.-1998.-840.-P. 33-44.

101. Iacobas D. A., Iacobas S., Thomas N., Spray D. C. Sex-dependent gene regulatory networks of the heart rhythm // Funct. Integr. Genomics.-2010.-10, N 1.-P. 73-86.

102. Yang J. N., Chen J. F., Fredholm B. B. Physiological roles of A1 and $\mathrm{A} 2 \mathrm{~A}$ adenosine receptors in regulating heart rate, body temperature, and locomotion as revealed using knockout mice and caffeine // Am. J. Physiol. Heart Circ. Physiol.-2009.-296, N 4.-P. H1141-1149.

103. Cifkova R., Skodova Z., Lanska V., Adamkova V., Novozamska E., Jozifova M., Plaskova M., Hejl Z., Petrzilkova Z., Galovcova M., Palous D. Prevalence, awareness, treatment, and control of hypertension in the Czech Republic. Results of two nationwide cross-sectional surveys in 1997/1998 and 2000/2001, Czech Post-MONICA Study // J. Hum. Hypertens.-2004.-18, N 8.P. 571-579.

104. Vokonas P. S., Kannel W. B., Cupples L. Epidemiology and risk of hypertension in the elderly: the framingham sudy // J. Hypertens. Suppl.-1988.-6, N 1.-P. S3-9.

105. Ong K. L., Cheung B. M., Man Y. B., Lau C. P., Lam K. S. Prevalence, awareness, treatment, and control of hypertension among united states adults 1999-2004 // Hypertension.-2007.-49, N 1.-P. 69-75.

106. Hart E. C., Charkoudian N., Miller V. M. Sex, hormones and neuroeffector mechanisms // Acta Physiol. (Oxf.).-2010.- doi: 10.1111/j.1748-1716.2010.02192.x.

107. Thireau J., Aimond F., Poisson D., Zhang B., Bruneval P., Eder $V$., Richard $S$., Babuty D. New insights into sexual dimorphism during progression of heart failure and rhythm disorders // Endocrinology.-2010.-151, N 4.-P. 1837-1845.

108. Roger V. L., Go A. S., Lloyd-Jones D. M., Adams R. J., Berry J. D., Brown T. M., Carnethon M. R., Dai S., de Simone G., Ford E. S., Fox C. S., Fullerton H. J., Gillespie C., Greenlund K. J., Hailpern S. M., Heit J. A., Ho P. M., Howard V. J., Kissela B. M., Kittner S. J., Lackland D. T., Lichtman J. H., Lisabeth L. D., Makuc D. M., Marcus G. M., Marelli A., Matchar D. B., McDermott M. M., Meigs J. B., Moy C. S., Mozaffarian D., Mussolino M. E., Nichol G., Paynter N. P., Rosamond W. D., Sorlie P. D., Stafford R. S., Turan T. N., Turner M. B., Wong N. $D$., Wylie-Rosett J., on behalf of the American Heart Association Statistics Committee and Stroke Statistics Subcommittee, Roger V. L., Turner M. B. and on behalf of the American Heart Association Heart Disease and Stroke Statistics Writing Group Heart Disease and Stroke Statistics 2011 Update: A Report from the American Heart Association // Circulation.-2011.123.-P. e18-e209.

109. Lujan H. L., Dicarlo S. E. Sex differences to myocardial ischemia and beta-adrenergic receptor blockade in conscious rats // Am. J. Physiol. Heart Circ. Physiol.-2008.-294, N 4.P. H1523-1529.

110. Bozkurt B. Where do we currently stand with advice on hormone replacement therapy for women? // Methodist Debakey Cardiovasc. J.-2010.-6, N 4.-P. 21-25.

111. Giardina E. G. Heart disease in women // Int. J. Fertil. Womens Med.-2000.-45, N 6.-P. 350-357.

112. Schwarz E. R., Dashti R. The clinical quandary of left and right ventricular diastolic dysfunction and diastolic heart failure // Cardiovasc. J. Afr.-2010.-21, N 4.-P. 212-220.

113. Kaku K., Takeuchi M., Otani K., Sugeng L., Nakai H., Haruki N., Yoshitani H., Watanabe N., Yoshida K., Otsuji Y., Mor-Avi $V$., Lang R. M. Age- and gender-dependency of left ventricular geometry assessed with real-time three-dimensional transthoracic echocardiography // J. Am. Soc. Echocardiogr.-2011.doi:10.1016/j.echo.2011.01.011.

114. Regitz-Zagrosek V., Oertelt-Prigione S., Seeland U., Hetzer R. Sex and gender differences in myocardial hypertrophy and heart failure // Circ. J.-2010.-74, N 7.-P. 1265-1273.

115. Hutchinson K. R., Stewart J. A., Lucchesi P. A. Extracellular matrix remodeling during the progression of volume overloadinduced heart failure // J. Mol. Cell. Cardiol.-2010.-48, N 3.P. 564-569.

116. Ky B., Kirwan B. A., de Brouwer S., Lubsen J., Poole-Wilson P. Otterstad J. E., Kimmel S. E., St. John Sutton M. Gender differences in cardiac remodeling and clinical outcomes in chronic stable angina pectoris (from the ACTION Trial) // Am. J. Cardiol.-2010.-105, N 7.-P. 943-947. 
117. Chan V., Fenning A., Levick S., Loch D., Chunduri P., Iyer A., Teo Y., Hoey A., Wilson K., Burstow D., Brown L. Cardiovascular changes during maturation and aging in male and female spontaneously hypertensive rats // J. Cardiovasc. Pharmacol.2011.-doi: 10.1097/FJC.0b013e3182102c3b.

118. Fliegner D., Schubert C., Penkalla A., Witt H., Kararigas G., Dworatzek E., Staub E., Martus P., Ruiz Noppinger P., Kintscher U., Gustafsson J. A., Regitz-Zagrosek V. Female sex and estrogen receptor-beta attenuate cardiac remodeling and apoptosis in pressure overload // Am. J. Physiol. Regul. Integr. Comp. Physiol.-2010.-298, N 6.-P. R1597-1606.

119. Satoh M., Matter C. M., Ogita H., Takeshita K., Wang C. Y., Dorn G. W., 2nd, Liao J. K. Inhibition of apoptosis-regulated signaling kinase- 1 and prevention of congestive heart failure by estrogen // Circulation.-2007.-115, N 25.-P. 3197-3204.

120. Ghali J. K., Krause-Steinrauf H. J., Adams K. F., Khan S. S., Rosenberg Y. D., Yancy C. W., Young J. B., Goldman S., Peber$d y$ M. A., Lindenfeld $J$. Gender differences in advanced heart failure: insights from the BEST study // J. Am. Coll. Cardiol.2003.-42, N 12.-P. 2128-2134.

121. Ghali J. K., Lindenfeld J. Sex differences in response to chronic heart failure therapies // Expert. Rev. Cardiovasc. Ther.-2008.6, N 4.-P. 555-565.

122. Gardner J. D., Murray D. B., Voloshenyuk T. G., Brower G. L., Bradley J. M., Janicki J. S. Estrogen attenuates chronic volume overload induced structural and functional remodeling in male rat hearts // Am. J. Physiol. Heart Circ. Physiol.-2010.-298, N 2.-P. H497-504.

123. Konhilas J. P., Leinwand L. A. The effects of biological sex and diet on the development of heart failure // Circulation.-2007.116, N 23.-P. 2747-2759.

124. Merz C. N. B., Olson M. B., McClure C., Yang Y.-C., Symons J., Sopko G., Kelsey S. F., Handberg E., Johnson B. D., CooperDeHoff R. M., Sharaf B., Rogers W. J., Pepine C. J. A randomized controlled trial of low-dose hormone therapy on myocardial ischemia in postmenopausal women with no obstructive coronary artery disease: Results from the National Institutes of Health/National Heart, Lung, and Blood Institutesponsored Women's Ischemia Syndrome Evaluation (WISE) // Am. Heart J.-2010.-159, N 6.-P. 987. e1-7.

125. Novakova M., Kvetnansky R., Myslivecek J. Sexual dimorphism in stress-induced changes in adrenergic and muscarinic receptor densities in the lung of wild type and corticotropin-releasing hormone-knockout mice // Stress.-2010.-13, N 1.-P. 22-35.

126. Goldstein J. M., Jerram M., Abbs B., Whitfield-Gabrieli S., Makris $N$. Sex differences in stress response circuitry activation dependent on female hormonal cycle // J. Neurosci.-2010.-30, N 2.-P. 431-438.

127. Garcia-Barrado M. J., Iglesias-Osma M. C., Moreno-Viedma V., Pastor Mansilla M. F., Gonzalez S. S., Carretero J., Moratinos J., Burks D. J. Differential sensitivity to adrenergic stimulation underlies the sexual dimorphism in the development of diabetes caused by Irs-2 deficiency // Biochem. Pharmacol.2011.-81, N 2.-P. 279-288.

128. Kumsta R., Entringer S., Koper J. W., van Rossum E. F., Hellhammer D. H., Wust $S$. Sex specific associations between common glucocorticoid receptor gene variants and hypothalamus- pituitary-adrenal axis responses to psychosocial stress // Biol. Psychiatry.-2007.-62, N 8.-P. 863-869.

129. van Rooij E., Fielitz J., Sutherland L. B., Thijssen V. L., Crijns H. J., Dimaio M. J., Shelton J., De Windt L. J., Hill J. A., Olson $E$. $N$. Myocyte enhancer factor 2 and class II histone deacetylases control a gender-specific pathway of cardioprotection mediated by the estrogen receptor // Circ. Res.-2010.-106, N 1.P. 155-165.

130. Pacanowski M. A., Zineh I., Li H., Johnson B. D., CooperDeHoff R. M., Bittner V., McNamara D. M., Sharaf B. L., Merz C. N., Pepine C. J., Johnson J. A. Adrenergic gene polymorphisms and cardiovascular risk in the NHLBI-sponsored Women's Ischemia Syndrome Evaluation // J. Transl. Med.-2008.6, N 1.-P. 11 .

131. Christiansen D. M., Elklit A. Risk factors predict post-traumatic stress disorder differently in men and women // Ann. Gen. Psychiatry.-2008.-7.-P. 24.

132. Olff M., Langeland W., Draijer N., Gersons B. P. R. Gender differences in posttraumatic stress disorder // Psychol. Bull.2007.-133, N 2.-P. 183-204.

133. Macabasco-O'Connell A., Crawford M. H., Stotts N., Stewart A., Froelicher E. S. Gender and racial differences in psychosocial factors of low-income patients with heart failure // Heart Lung.-2010.-39, N 1.-P. 2-11.

134. Huzen J., van der Harst P., de Boer R. A., Lesman-Leegte I., Voors A. A., van Gilst W. H., Samani N. J., Jaarsma T., van Veldhuisen $D$. J. Telomere length and psychological well-being in patients with chronic heart failure // Age Ageing.-2010.-39, N 2.-P. 223-227.

135. Wong L. S., Oeseburg H., de Boer R. A., van Gilst W. H., van Veldhuisen D. J., van der Harst $P$. Telomere biology in cardiovascular disease: the $\mathrm{TERC}^{-/-}$mouse as a model for heart failure and ageing // Cardiovasc. Res.-2009.-81, N 2.-P. 244-252.

136. Lee K. S., Song E. K., Lennie T. A., Frazier S. K., Chung M. L., Heo S., Wu J.-R., Rayens M. K., Riegel B., Moser D. K. Symptom clusters in men and women with heart failure and their impact on cardiac event-free survival // J. Cardiovasc. Nurs.2010.-25, N 4.-P. 263-272.

137. Neckelmann D., Mykletun A., Dahl A. A. Chronic insomnia as a risk factor for developing anxiety and depression // Sleep.2007.-30, N 7.-P. 873-880.

138. Hayes D. Jr., Anstead M. I., Ho J., Phillips B. A. Insomnia and chronic heart failure // Heart Fail. Rev.-2009.-14, N 3.-P. 171182.

139. Cocco G., Chu D. Stress-induced cardiomyopathy: a review // Eur. J. Intern. Med.-2007.-18, N 5.-P. 369-379.

140. Primetshofer D., Agladze R., Kratzer H., Reisinger J., Siostrzonek $P$. Tako-Tsubo syndrome: an important differential diagnosis in patients with acute chest pain // Wien. Klin. Wochenschr.-2010.-122, N 1.-P. 37-44.
UDC $616.1+612.176$

Received 10.01.11 